\title{
Identifying Industrial Clusters For Regional Economic Diversification: The Case Of South Africa's North West Province
}

Noleen Pisa, North-West University, Potchefstroom Campus, South Africa

Riaan Rossouw, North-West University, Potchefstroom Campus, South Africa Wilma Viviers, North-West University, Potchefstroom Campus, South Africa

\begin{abstract}
Dependency on commodity exports is seen as a structural weakness in resource dependent regions. Not surprisingly, such regions have made economic diversification a key priority. The economy of South Africa's North West Province (NWP), a rich platinum and gold mining region, is highly specialised and dependent on a few sectors. This paper proposes industrial cluster formation as a means of diversifying the NWP economy and enhancing competitiveness in the province. The structural path analysis and Power-of-Pull methods were used to identify and rank order the industrial clusters that offer the greatest economy-wide benefits, while also creating opportunities for cross-sectoral collaboration.
\end{abstract}

Keywords: Industrial Clusters; Competitiveness; Regional Economic Development; Resource Dependency; Diversification

\section{INTRODUCTION}

ommodities make a significant contribution to many countries' economies as they are an important source of export revenue and employment for a large proportion of the labour force (Bower, Geis \& Winkler, 2007). Growth in resource dependent regions is mainly driven by high and rising commodity prices. But a dependency on commodity exports has been identified as a structural weakness in these economies, especially in the wake of the global economic crisis of 2008/09 when precipitous declines in the prices of several commodities impacted negatively on many countries' growth prospects (Sindzingre, 2011; Kingstone, 2012). High volatility in commodity prices, which has become the norm in recent years, discourages long-term investment and makes it difficult to achieve stable growth (UNCTAD, 2012). Not surprisingly, many countries have in recent years made diversification of economic activities a priority.

The formation of industrial clusters can bring about greater economic stability in a country. This is because clusters, by spanning a wide range of sectors, can give rise to the full spectrum of regional economic diversification possibilities (Eitzen, 2012). Porter (2000:7) defines industrial clusters as "geographically close groups of interconnected companies and associated institutions in a particular field linked by common technologies and skills". By serving as internal engines that power up and grow national economies, industrial clusters and regional economic development initiatives lay the foundation for economy-wide diversification and stimulate technical as well as knowledge spill-overs (Chapman, Mackinnon \& Cumbers, 2004; Birch, Mackinnon \& Cumbers, 2010; Eitzen, 2012).

The economy of South Africa's North West Province (NWP), a major platinum and gold mining subnational economy, is highly specialised, with commercial activity being concentrated in four sectors: mining and quarrying; financial services; general government; and wholesale trade. Together these four sectors account for $67.5 \%$ of the total provincial output (Quantec Easy Data, 2014). Such concentration of activity leaves the province vulnerable to periodic, or even sustained, economic downturns if, for example, a key sector such as mining 
experiences waning demand and/or production problems. This inevitably has repercussions for the national economy as a whole.

Evidence of the repercussions of dependence on commodities, on both the NWP and South African economies, was reflected in the impacts of the 2014 platinum sector strike. The prolonged 2014 platinum strike in South Africa adversely affected global supply of minerals and mineral products, South Africa's economic growth, mining companies' revenues and workers' remuneration (Singh, 2014; Solomons; 2014; Alers, 2014). Economic activity and economic growth in South Africa contracted in the first quarter of 2014 with real gross domestic product (GDP) declining to $-0.6 \%$, in the first quarter of 2014 compared to $3.8 \%$ in the last quarter of 2013 (SARB, 2014). Mining production decreased by 6.5\% year-on-year in May 2014 (SARB, 2014). In particular, the largest negative growth rates were recorded for platinum group metals $(-48.5 \%)$, other non-metallic minerals $(-13.3 \%)$ and building materials (-11.7\%). In terms of platinum supply, 440000 ounces of platinum production was lost. The three major companies in the sector; Impala Platinum, Amplats and Lonmin suffered a total revenue loss of about R24.1billion during the strike while the workers incurred a further loss of R10.6 billion in wages (Platinum Wage Negotiations, 2014).

The negative spillover effects of the platinum strike further adversely affected other sectors in the economy, particularly manufacturing, petroleum, basic chemicals and iron ore (Singh, 2014). The processing of minerals makes up about $15 \%$ of the economy locally and about $40 \%$ of global production of the precious metal, which is used for catalytic converters in vehicles and is a key source of hard currency for South Africa (Singh, 2014). The mining industry accounts for $8.6 \%$ of GDP and another $10 \%$ through the multiplier effect (DTI / Deloitte, 2014). Of the $8.6 \%$, the NWP mining sector contributes $31 \%$ to the national output (Quantec Easy Data, 2014). This highlights the imminent need for the NWP to develop strategies to diversify its economy. Against this background, the main aim of this paper is to identify industrial clusters in the NWP which would form the basis of a strategy to diversify economic activity and sustainably enhance competitiveness in the province.

Against this background, the main aim of this paper is to identify industrial clusters in the NWP which would form the basis of a strategy to diversify economic activity and sustainably enhance competitiveness in the province. The rest of this paper is organised as follows: Section 2 provides a background on the strategy of economic diversification through industrial cluster formation, a discussion on the benefits of industrial cluster formation, and an overview of the economy of South Africa's NWP. Section 3 describes the methods used to identify industrial clusters in the NWP, while Section 4 discusses the results. Section 5 brings the paper to a close with some concluding remarks.

\section{THE INDUSTRIAL CLUSTER PHENOMENON}

\subsection{Economic Diversification Through Industrial Cluster Formation}

Resource dependent regions are vulnerable to the unpredictable nature of market demand for the resources that they produce, thus creating intermittent risks for these regions' growth prospects (Eitzen, 2012). Such risks include: a high probability of loss of export revenues; a crowding out of other economic activities, especially manufacturing; and the real exchange rate being subjected to constant pressure (Kingstone, 2012). Economic diversification literature emphasises that specialisation in niche sectors should be pursued once high levels of economic growth have been realised. Following on from this thinking, resource dependent regions that have enjoyed the initial gains from specialising in sectors in which they have a comparative advantage, should pursue a diversification strategy in order to enhance economic growth (Imbs \& Wacziarg, 2003; OECD/United Nations, 2011).

The arguments in favour of diversification are traditionally presented from a national, country-wide perspective. Yet it should not be forgotten that commodity dependency has particular sub-national or regional impacts since natural resources are not distributed evenly across a country (Ross, Lujala \& Rustad, 2012). Grounded in the new economic geography view, economic development efforts in recent times are focusing to an increasing extent on regional economic development policies. These policies are aimed at improving regional production systems and promoting emerging and/or existing industrial clusters. Ultimately, the consolidated efforts are intended 
to enhance firm, regional and national competitiveness and create a climate conducive to growth and development (National Governors Association (NGA), 2002; Shields, Barkley \& Emery, 2010).

One of the most widely cited authors on the subject of industrial clusters is Porter. Porter (1998) stresses that industrial clusters, due to the nature of their networks and external linkages, do not necessarily conform to Standard Industrial Classification (SIC) systems and as a result, they comprise firms from different sectors or industries. Industrial clusters can facilitate both structural change and innovation, and be used as engines of crosssectoral fertilisation (Bryan et al., 2005; Bishop \& Gripaios, 2007; Malacarne, 2013). Cross-sectoral fertilisation results from collaboration among firms from different sectors or industries, which gives rise to knowledge transfer, innovation, new product development and more effective value chains (Malacarne, 2013). The collaborative nature of industrial cluster formation encourages diversification in industry specialisation patterns and helps to boost economic prosperity (Malacarne, 2013). Furthermore, investment flows to the multiple industries making up industrial clusters provide a source of economic security and stability.

Industrial clusters are seen to offer the key to diversified national growth (Eitzen, 2012) because firms in a particular cluster will specialise in those areas in which their competitive advantage lies and will outsource activities in which they are less efficient, relative to other firms in the cluster. Through specialisation, firms in clusters become more efficient and more productive (Madsen, Smith \& Dilling-Hensen, 2004), and this leads to heightened competitiveness and productivity in other sectors making up the cluster. Industrial cluster formation transforms the character of a region from one of resource dependency to one of rich economic potential (Bishop \& Gripaios, 2007; Eitzen, 2012). Bishop and Gripaios (2007) pointed out that the promotion of diversified regions is not necessarily inconsistent with policies aimed at developing key industries. Economic diversification can be achieved through the establishment of strong industrial clusters in different sectors of the economy. The gains from specialisation in industrial clusters, combined with the long-term flexibility and dynamism associated with diversification, can produce long-term benefits for the regional economy as a whole.

\subsection{The Benefits Of Industrial Cluster Formation}

Empirical evidence supports the notion that firms in clusters display higher levels of knowledge integration, innovation, global competence, adaptability to change in the external environment, growth and sustainable development (Porter, 1998; Morosini, 2004). Furthermore, industrial clusters are repositories of specialised and flexible labour markets, capital, and research and development capabilities (Doeringer \& Terkla, 1995; Lee, 2006). This gives firms access to the skills, knowledge and research and development findings of other firms in the cluster. For example, innovation is enhanced by the existence of, and close proximity to, research institutions, thus building firms' critical mass in research and development. This, in turn, is facilitated by the existence of qualified labour, strong relationships and dense networks, which ensure the diffusion of knowledge about markets and technology (Chiaroni \& Chiesa, 2006). Additionally, the geographical proximity of buyers, suppliers and firms in clusters creates short feedback loops for ideas and innovations, which leads to faster and more effective knowledge diffusion (Enright, 2003; Torre, 2008). Geographical proximity also enables specialists to move easily between the different firms and engage in personal communication with people undergoing training (Porter, 2002; Torre, 2008).

Industrial clustering gives rise to collective efficiency gains - an outcome that small firms would have been unlikely to realise when operating individually (Schmitz, 1995, 1997; Schmitz \& Nadvi, 1999). It increases the likelihood of firms, which might otherwise have been fierce local rivals in the absence of the cluster arrangement, embarking on consensual and reciprocal division of labour and specialisation (Schmitz, 1995), thereby enabling them to utilise specialised machinery more productively and achieve higher utilisation rates (Marshal, 1920). The division of labour also allows firms in the cluster to specialise in a limited range of production activities, save on both working and fixed capital costs, and procure materials and parts in a more flexible manner (Ruan \& Zhang, 2009).

Industrial clusters also create opportunities for new companies to be formed and new lines of business to be initiated. This is prompted by the presence of commercial relationships, as well as concentrated demand, more accessible capital and lower barriers to entry (Porter, 2002). The networks and relationships that characterise industrial clusters are instrumental in disseminating, first-hand, information about suppliers' offerings and 
highlighting any gaps in product or service provision, which in turn might reveal new business opportunities (Porter, 2002). Research institutions can play a key role in the process by uncovering new and unexploited business opportunities through their research findings.

Industrial cluster formation enhances the economic performance of firms (Doeringer \& Terkla, 1995; Schmitz, 1999; Lee, 2006; Sonobe \& Otsuka, 2006). By being afforded access to better materials, capital machinery, skilled labour and networks, a firm is able to produce and market a better product and generate higher profits. Being part of a cluster also entitles firms to various resources, i.e. infrastructure, collective bargaining and specialised services. Furthermore, such firms enjoy lower transport and transaction costs, thus reducing operational costs and enhancing profitability.

\subsection{South Africa's North West Province (NWP)}

South Africa's North West Province (NWP) is situated in the north-western part of South Africa, on the Botswana border, and its provincial capital is Mafikeng (source). The NWP covers a total area of 106512 square kilometres (accounting for $8.7 \%$ of South Africa's land area), thereby making it the fifth largest province in the country (Statistics South Africa, 2013). Table 1 shows the total (all industries) gross value added (GVA) for the nine provinces in South Africa in 2013. The NWP is the $7^{\text {th }}$ largest contributor of national output (GVA), accounting for $6.9 \%$ of the total (Quantec Easy Data, 2013).

Table 1 also shows the tress index scores calculated for the nine different provinces and for South Africa in 2012. This index is used to show the extent to which an economy is concentrated or diversified, which also indicates the structural risk of a particular area. The more dependent an area is on a single (or few) sector(s) for its economic activity, the greater is the risk that the area will experience economic hardship if a single (or few) sector(s) goes into decline (Hall \& Whiteford, 1998). The tress index of the province is therefore estimated by ranking the nine provinces according to their contributions to GVA or employment, adding the values cumulatively and then indexing them. The index ranges between 0.0 and 100.0, where an index value greater than 50.0 indicates that the economy is relatively concentrated and an index value less than 50.0 indicates that the economy is diversified. In the context of risk, the closer the index is to 100.0 , the greater is the structural risk for the area (Hall \& Whiteford, 1998). The tress index values show that all the provinces, with the exception of Mpumalanga and Kwazulu-Natal, are more specialised than the national economy. The index value for the NWP is 75.5, indicating that economic activity is highly concentrated in a few sectors. This implies that the NWP has a high structural risk.

Table 1. Total Output Per Province And For South Africa In 2013

\begin{tabular}{lcccc}
\hline \multicolumn{1}{c}{ Place } & $\begin{array}{c}\text { Gross value added } \\
\text { (GVA) current prices; } \\
\text { ZAR trillions) }\end{array}$ & $\begin{array}{c}\text { Share of total GVA } \\
(\%)\end{array}$ & $\begin{array}{c}\text { Ranking of province's } \\
\text { contribution to GVA }\end{array}$ & $\begin{array}{c}\text { Tress index } \\
\text { (ave. 23 industries) } \\
\text { in 2013 }\end{array}$ \\
\hline Western Cape & 0.431 & 14.2 & 3 & 70 \\
Eastern Cape & 0.229 & 7.5 & 4 & 72 \\
Northern Cape & 0.069 & 2.3 & 9 & 76 \\
Free State & 0.161 & 5.3 & 8 & 69 \\
Kwazulu-Natal & 0.480 & 15.9 & 2 & 64 \\
North West & 0.197 & 6.5 & 7 & $\mathbf{7 6}$ \\
Gauteng & 1.035 & 34.2 & 1 & 69 \\
Mpumalanga & 0.213 & 7.0 & 6 & 66 \\
Limpopo & 0.215 & 7.1 & 5 & 77 \\
South Africa & 3.030 & 100.0 & & $\mathbf{6 6}$ \\
\hline Source: Quntec
\end{tabular}

Source: Quantec Easy Data, 2014

Table 2 shows the NWP's and South Africa's output per sector in 2013. Output in South Africa is concentrated in the secondary sector, particularly in manufacturing, as well as in the tertiary sector. In contrast, output in the NWP is concentrated in the primary and government services sectors, which presents a different picture when compared to the national economy. The table further illustrates that economic activity in the NWP is highly specialised. The main economic activity in the province in terms of contribution to output is mining and quarrying, which accounted for $31 \%$ of provincial GVA in 2013. Other sectors making a significant contribution to 
total provincial output in 2013 were finance, insurance, real estate and business services (14.8\%), general government services (14.5\%), and wholesale and retail trade, catering and accommodation (12.5\%).

Table 2. Output Per Sector In South Africa And In The NWP In 2013

\begin{tabular}{|c|c|c|c|c|c|c|}
\hline \multirow[b]{2}{*}{ Sector } & \multicolumn{3}{|c|}{ South Africa } & \multicolumn{3}{|c|}{ NWP } \\
\hline & $\begin{array}{l}\text { GVA (current } \\
\text { prices; } \\
\text { ZAR trillions) }\end{array}$ & $\begin{array}{l}\text { Sector's share } \\
\text { of national } \\
\text { GVA (\%) }\end{array}$ & $\begin{array}{c}\text { Sector's } \\
\text { ranking in } \\
\text { national GVA }\end{array}$ & $\begin{array}{l}\text { GVA (current } \\
\text { prices; } \\
\text { ZAR billions) }\end{array}$ & $\begin{array}{c}\text { Sector's share } \\
\text { of provincial } \\
\text { GVA }(\%)\end{array}$ & $\begin{array}{l}\text { Sector's } \\
\text { ranking in } \\
\text { provincial } \\
\text { GVA }\end{array}$ \\
\hline $\begin{array}{l}\text { Agriculture, forestry and } \\
\text { fishing }\end{array}$ & 0.072 & 2.4 & 10 & 0.048 & 2.5 & 9 \\
\hline Mining and quarrying & 0.280 & 9.2 & 5 & 0.610 & 31.0 & 1 \\
\hline Manufacturing & 0.350 & 11.6 & 4 & 0.096 & 4.9 & 7 \\
\hline Electricity, gas and water & 0.092 & 3.0 & 9 & 0.027 & 1.4 & 10 \\
\hline Construction & 0.114 & 3.7 & 8 & 0.050 & 2.5 & 8 \\
\hline $\begin{array}{l}\text { Wholesale and retail } \\
\text { trade, catering and } \\
\text { accommodation }\end{array}$ & 0.502 & 16.6 & 3 & 0.245 & 12.5 & 4 \\
\hline $\begin{array}{l}\text { Transport, storage and } \\
\text { communication }\end{array}$ & 0.269 & 8.9 & 6 & 0.152 & 7.7 & 6 \\
\hline $\begin{array}{l}\text { Finance, insurance, real } \\
\text { estate and business } \\
\text { services }\end{array}$ & 0.652 & 21.5 & 1 & 0.291 & 14.8 & 2 \\
\hline $\begin{array}{l}\text { Community, social and } \\
\text { personal services }\end{array}$ & 0.180 & 6.0 & 7 & 0.163 & 8.3 & 5 \\
\hline General government & 0.518 & 17.1 & 2 & 0.285 & 14.5 & 3 \\
\hline Total industries & 3.030 & 100 & & 1.968 & 100 & \\
\hline
\end{tabular}

Source: Quantec Easy Data, 2014

Tables 1 and 2 highlight that the NWP economy is highly specialised and dependent on just a few sectors. A high dependency on mining and quarrying, in particular, makes the province more vulnerable to external shocks and currency fluctuations. Furthermore, resource dependency means that the provincial economy is prone to macroeconomic instability and crowds out domestic industry such as manufacturing (Eitzen, 2012). Manufacturing is crucial for sustainable economic development. Yet specialisation in resources results in manufacturing losing ground on the development front (Kingstone, 2012). It is against this backdrop that this paper will identify industrial clusters in the NWP of South Africa as a strategy to sustainably diversify economic activity and enhance competitiveness in the province.

\section{METHODS}

Several methods to identify industrial clusters are evident in the literature (Roelandt \& Hertog, 1999). Some of these methods appear frequently, while others are relatively scarce. (For an overview of the literature, see Pisa, 2014). Among the methods that have been used in empirical studies to identify industrial clusters are: location quotient, Ellison-Glaeser index, local Moran statistic, shift share analysis, locational correlation, wage analysis, graph theory/network analysis, and spectral clustering. Shields, Barkley \& Emery (2010) assert that most of these methods share two common aims, namely:

1. Identifying a cluster that has the highest potential for growth and expansion. This involves a detailed analysis of sector trends to identify matches between clusters and regional characteristics; and

2. Narrowing down potential sectors to reveal a small set of clusters that best fit the characteristics of the region. This approach, although subjective, involves arriving at a list of sectors that deliver the greatest impact in terms of local economic development, as evidenced, for example, in job creation, high wages, a high contribution to the local tax base, and a negligible environmental footprint. Targeting in this way encourages the efficient use of limited resources for economic development.

3. For the purpose of this paper, industrial clusters in the NWP of South Africa were identified by applying the structural path analysis (SPA) method, which involves analysing existing inter-industry linkages in the 
2006 social accounting matrix (SAM) for the NWP. The SPA method has, compared with other available methods, a number of distinguishing features that make it superior in the industrial cluster identification process. SPA is a decomposition technique, based on the theory that the 'connections' for transmitting a particular desired outcome in the economy lie in the different sectors of the economy (Kagawa et al., 2010). It can identify clusters by tracing the sectors with the strongest inter-linkages and identifying how those sectors link up with the rest of the economy. In addition, it is able to provide insights into the possible outcomes of certain policies, achieved through the identification of the key interactions or paths within an economic system that are important transmitters of economic influence (Ngandu et al., 2010). The SPA method provides for the isolation and identification of the distinctive reaction mechanisms within the complex network of structural relations among the different economic agents (Roberts, 2005). Additionally, the SPA method was used because of two other factors, which are specifically relevant to the NWP of South Africa namely (i) the NWP SAM was readily available (DBSA SAM of 2006); and (ii) a SAM will incorporate the geographic scope of cluster definitions, which is the geographic concentration of firms in the NWP.

\subsection{Data: Description Of The NWP SAM Accounts}

The 2006 social accounting matrix (SAM) for the NWP, which captures the economic structure of the province, was used to identify industrial clusters. The 2006 SAM is the most recent version available for the NWP. This is because "data typically used to build SAMs include input-output (I-O) tables of the economy, national accounts, fiscal accounts, trade data, other balance-of-payments information, and surveys providing information on the composition of household income and expenditures" (Debowicz, Dorosh, Haider \& Robinson, 2013: 2). In contrast to national income and product data that are produced annually, I-O tables are compiled at five-year intervals (Robinson, Cattaneo \& El-Said, 1997). Therefore, SAMs tend to be published less often because of their reliance on census and survey data to provide highly disaggregated data (Harun, Zakariah \& Azali, 2012). Censuses and surveys are conducted sporadically, thereby rendering SAMs sporadic. However, the actual structure of an economy and the inter-linkages among its various economic components do not change very much over time. Consequently, it is still acceptable to use the 2006 SAM for the NWP.

\subsection{Structural Path Analysis (SPA)}

SPA identifies the types of linkages that work inside the economy by highlighting the changes in the levels of intermediate flows between sectors (Lima et al., 2003). This paper follows Parra and Wodon's (2009) description of the SPA method and applies the method to the 2006 SAM for the NWP to identify industrial clusters.

The SPA was conducted using the program, SimSIP SAM. It is a Microsoft Excel tool, developed by the World Bank, which utilises MATLAB to analyse I-O and SAM tables (Parra \& Wodon, 2009). Fixed origin analysis was conducted in SimSIP SAM. SPA involves dividing accounts in the SAM into endogenous and exogenous types. SPA first decomposes SAM multipliers into direct and indirect components, and reveals the network through which transmission occurs. This is achieved by exposing the channels through which influence is transmitted in a macroeconomic system (Hirshman, 1958; Defourny \& Thorbecke, 1984). The backward linkages or diffusion effects are calculated as follows:

$\mathrm{BL}_{j}=\frac{B_{j}}{\frac{1}{n} v}, j=1 \ldots n$

The forward linkages or absorption effects are calculated as follows:

$\mathrm{BL}_{i}=\frac{B_{i}}{\frac{i}{n} v}, i=1 \ldots n$

Where $B$ represents the sectorial interdependences in an economy or the Multiplier Product Matrix (MPM). The subindexes $\mathrm{i}, \mathrm{j}$ make reference respectively to the rows and columns of the corresponding matrices. $n$ is the number of endogenous variables in the SAM that is, the productive sectors, the production factors and the consumers. $v$ is a 
global intensity factor that corresponds with the sum of all the elements of the associate inverse matrix. If the backward linkages are greater than 1, it implies that a unit change in the final demand of sector $j$ will generate an increase above the average in the global activity of the economy (Lima et al., 2003). If the forward linkages are greater than 1, it implies that a unit change in all the sectors of the final demand will generate an increment above the average in sector $i$. A key sector is the one with both indexes greater than 1 (Lima et al., 2003).

The second step in SPA is to decompose accounting multipliers or the global influence in a SAM. Multipliers are decomposed into total influence according to the respective elementary paths flowing from two given poles (Defourny \& Thorbecke, 1984). Given the technical coefficients matrix $A_{n x n}$, any of the endogenous accounts in the 2006 NWP SAM are taken as a pole. Any two poles (endogenous accounts) $i$ and $j$ are connected by an arc-arc $(i, j)$. The intensity of the inter-industry linkages between $i$ and $j$ is given by $a_{i j}$ in the $A_{n x n}$ matrix. Consecutive arcs define a path while the length of the path is determined by the number of arcs in the paths. An elementary path in SPA is one that does not visit any pole more than once. A path that starts and ends at the same pole is known as a circuit.

SPA distinguishes three types of influences, namely direct, total and global influences. The direct influence of $i$ on $j$ through an elementary path refers to the change in income on sector $j$ caused by a unitary injection in sector $I$, and this is given as the product of the intensities of all arcs in the path. The direct influence only includes the incomes of poles (sectors) in the elementary paths (Shantong, Ying \& Jianwu, 2004). The direct influence from $i$ to $j$ through the elementary path $p$ is given by the product of the intensities of all arcs constituting the path. For example, the direct influence caused by the elementary path $i \rightarrow k \rightarrow m \rightarrow j$ is given by:

$I_{i \rightarrow j}^{D}=a_{k i} a_{m k} a_{j m}$

Usually several interactions occur among the different poles (sectors) in the economy. This results in poles in the elementary paths being linked to other poles and paths thus forming circuits. All these interactions amplify the direct influence of the elementary path (Defourny \& Thorbecke, 1984). The total Influence of an injection in sector $i$ on sector $j$ includes all possible paths of transmitting influence between the two poles $i$ and $j$. This includes the direct influence through the elementary paths as well as the indirect influences in other paths and the circuits. Using the geometric series argument, the total influence can be calculated using equation (4) below:

$I_{(i \rightarrow j) p}^{T}=a_{k i} a_{m k} a_{j m}\left[1-a_{m k}\left(a_{k m}+a_{f m} a_{k f}\right)\right]^{-1}$

The first product of equation (4) is the direct influence along the path $p$, and the second term is called the path multiplier $M p$.

Finally, SPA calculates the global influence. The global influence does not follow a specific path in the transmission of an influence, as is the case with the direct influence. Instead, the global influence includes the total effects - i.e. induced and feedback effects - of an injection of one unit of either income or output in pole $i$ (Defourny $\&$ Thorbecke, 1984). This includes total effects on income and output on pole $j$. The global influence is given by equation (5):

$I_{i \rightarrow j}^{G}=\sum_{p=1}^{n} I_{(i \rightarrow j) p}^{T}=\sum_{p=n}^{n} I_{(i \rightarrow j) p}^{D} M_{p}$

For detailed exposition of the matrix algebra presented in this section refer to Parra and Wodon (2009), Shantong et al. (2004) and Defourny and Thorbecke (1984). The SPA method, however, does not determine the optimal number of clusters. It shows different clusters and how they are interconnected with the rest of the economy, but does not show the most important cluster with the greatest economy-wide effects. In light of this, the PoP method was used to prioritise the number of clusters. 


\subsection{Power-of-Pull (PoP)}

After performing the SPA, the PoP method was used to prioritise the number of clusters for the NWP. This is the first study to our knowledge to use the PoP method to prioritise the number of industrial clusters. This is essential for the effective promotion of industrial clusters because governments have limited resources (Martin \& Sunley, 2003). Therefore, to ensure the effective utilisation of these limited resources, industrial clusters with the highest potential benefits and chances of success should be targeted. The PoP method helps to achieve this. It defines network effects as a quantifiable criterion that can be used to determine the industrial clusters that should be prioritised (Luo, 2013). The underlying principle of this method is to focus on sectors that have the ability to 'pull' themselves and the activities and output of all other sectors. The latter include those sectors to which the identified sectors are connected, either directly or indirectly, throughout the economy. This ability of a sector is referred to as the PoP.

The PoP method allows the observation of the clusters' overall impact in generating additional output, both in the clusters themselves and in the rest of the economy (Luo, 2013). A cluster with a high PoP comprises sectors that it pulls and that have high PoPs, and these sectors' PoP are determined by the sectors that they further pull ad infinitum (Wasserman \& Faust, 1994; Newman, 2008). The PoP method reveals fundamental structural changes in the economy, highlighting the key influencing sectors for long-term growth and development.

The earliest approach to calculating the PoP of individual sectors was proposed as an infinite regress problem by Seeley (1949). Following Dietzenbacher's (1992) study, we assume $\mathbf{r}_{i}$ to be a vector of power indicators of the sectors, and the indicator vector $r_{i+1}$ is updated as the sum of backward linkages (columns of the A matrix) weighed by the normalised $r_{i}$ from the previous iteration. The inputs from a sector with high pulling power receive a larger weight than the inputs from a sector with lower pulling power. The power scores, which are also used as the weighting factors, are normalised to have an average of 1 . The power scores take the following form:

$r_{i+1}=n \grave{r}_{l} A / \grave{r_{l}} A e$

Where $n$ is the total number of sectors and $\mathbf{e}$ is the column summation vector $(e i=1$ for all $i)$. Then, the estimation of sector power indicator can be improved through iterations to infinitum $(i \rightarrow \infty)$.

Estimates of a sector's power indicator improve through iterations to infinitum $(i \rightarrow \infty)$. Furthermore, according to Dietzenbacher (1992), "the indicator converges to the normalised left-hand eigenvector corresponding to the dominant eigenvalue (i.e. the Perron vector) of the input coefficient matrix A". The indicator vector can be calculated as $n q^{\prime} /\left(q^{\prime} \mathrm{e}\right)$ with:

$\dot{q}=\lambda \dot{q}$

Where $\mathrm{q}^{\prime}$ is the dominant eigenvalue of the A matrix.

The elements of $n \mathrm{q}^{\prime} /\left(\mathrm{q}^{\prime} \mathrm{e}\right)$ indicate how powerfully the activities of sectors may pull the activities (thus outputs) of the overall economic network (including themselves), i.e. the Power-of-Pull. For more details on this method, including its derivation, see Dietzenbacher (1992).

\section{RESULTS AND DISCUSSION: INDUSTRIAL CLUSTERS IDENTIFIED}

This is the first study to our knowledge to apply the SPA and PoP methods to identify industrial clusters. Furthermore, it is the first study to our knowledge to apply these two methods to South African provincial data. Ten industrial clusters were identified and prioritised for the NWP, which are shown in Table 3 . The table also shows the direct measures according to the NWP SAM. The PoP is a sector's power to pull all sectors through direct and indirect linkages in the network (Newman, 2008). As a result, the ranking of clusters by PoP may differ significantly from that given by direct measures (intermediate input, commodity output and value added) in the SAM. Direct measures indicate the size or volume of a sector (Luo, 2013). Table 3 presents the PoP values and ranks, as well as 
the direct measures, namely intermediate input, commodity output and value added of the ten identified industrial clusters for the NWP.

Table 3. Ranking By PoP And Direct Measures Of The Ten Identified Industrial Clusters For The NWP In 2006

\begin{tabular}{|c|c|c|c|c|c|c|c|c|}
\hline \multirow[b]{2}{*}{ Sector } & \multicolumn{2}{|c|}{ PoP } & \multicolumn{2}{|c|}{$\begin{array}{c}\text { Intermediate Input } \\
\text { (SAM) }\end{array}$} & \multicolumn{2}{|c|}{$\begin{array}{c}\text { Commodity Output } \\
\text { (SAM) }\end{array}$} & \multicolumn{2}{|c|}{ Value Added (SAM) } \\
\hline & Value & Rank & $\begin{array}{c}\text { Value } \\
\text { (ZAR } \\
\text { millions) }\end{array}$ & Rank & $\begin{array}{c}\text { Value } \\
\text { (ZAR } \\
\text { millions) }\end{array}$ & Rank & $\begin{array}{c}\text { Value } \\
\text { (ZAR } \\
\text { millions) }\end{array}$ & Rank \\
\hline Communication & 2.435 & 1 & 5,165 & 10 & 8,565 & 10 & 3,400 & 10 \\
\hline Real estate & 2.392 & 2 & 11,175 & 2 & 16,496 & 4 & 5,320 & 7 \\
\hline $\begin{array}{l}\text { Grain mill, bakery and } \\
\text { animal feed }\end{array}$ & 2.341 & 3 & 2,527 & 14 & 2,961 & 17 & 434 & 21 \\
\hline $\begin{array}{l}\text { Building and other } \\
\text { construction }\end{array}$ & 2.326 & 4 & 7,295 & 4 & 9,358 & 8 & 2,063 & 12 \\
\hline Basic metal products & 2.234 & 5 & 3,662 & 11 & 4,260 & 12 & 598 & 17 \\
\hline Other food products & 2.140 & 6 & 238 & 33 & 356 & 32 & 118 & 32 \\
\hline Agriculture & 2.132 & 7 & 5,269 & 9 & 8,454 & 11 & 3,185 & 11 \\
\hline $\begin{array}{l}\text { Non-metallic mineral } \\
\text { products }\end{array}$ & 2.075 & 8 & 2,049 & 16 & 3,311 & 15 & 1,262 & 13 \\
\hline Trade & 2.030 & 9 & 10,441 & 3 & 21,982 & 2 & 11,541 & 2 \\
\hline Dairy products & 1.986 & 10 & 1,627 & 19 & 1,877 & 20 & 249 & 25 \\
\hline
\end{tabular}

Source: Authors' own calculations based on Conningarth Economists 2006 NWP SAM (2009) and PoP results

The communication cluster was identified as having the highest PoP in the NWP in 2006. However, it ranked $10^{\text {th }}$ by intermediate input, commodity output and value added, respectively. This indicates that the communication sector is not big, but it is powerful. The high ranking on the PoP for the communication cluster implies that its activities strongly pull the activities of other sectors throughout the NWP economy. The real estate cluster ranked $2^{\text {nd }}$ by PoP ( $2^{\text {nd }}$ by intermediate input, $4^{\text {th }}$ by commodity output and $7^{\text {th }}$ by value added $)$. Similarly, the trade cluster ranked $9^{\text {th }}$ by PoP $\left(3^{\text {rd }}\right.$ by intermediate input and $2^{\text {nd }}$ by commodity output and value added, respectively). This shows that both the real estate and trade clusters in the NWP are big and powerful.

The grain mill, bakery and animal feed products cluster indicates further that size does not equal power or importance. It ranked $3^{\text {rd }}$ by PoP $\left(14^{\text {th }}\right.$ by intermediate input, $17^{\text {th }}$ by commodity output and $21^{\text {st }}$ by value added $)$. Similarly, the other food products cluster ranked $6^{\text {th }}$ by PoP $\left(33^{\text {rd }}\right.$ by intermediate input and $32^{\text {nd }}$ by commodity output and value added, respectively), while dairy products ranked $10^{\text {th }}\left(19^{\text {th }}\right.$ by intermediate input, $20^{\text {th }}$ by commodity output and $25^{\text {th }}$ by value added). The ten clusters presented in Table 3 received the highest rankings for PoP, indicating that these clusters generate the largest economy-wide or network-wide effects compared with those from the direct accounts of individual sectors. These industrial clusters that were identified for the NWP will be discussed in detail.

SPA is a construct of relationships within the economy. This paper presents a graphical representation of the SPA results allowing a potentially straightforward interpretation of this construct (Ngandu et al., 2010). The lines represent the inter-industry linkages between the sectors, while the absence of a line between sectors represents the absence of inter-linkages. The thickness of the lines connecting the industry sectors in the figures represents the strength of the connection or the relative volume of flow or strength of the inter-linkages along the path between the corresponding industry sectors. The thickest lines represent the greatest flow volume, while the thin lines represent the least relative flow volume along the path. It is important to note that the thickness is not related to income magnitudes. Rather, the importance of the path relates to both its influence and the path multiplier of adjacent circuits (Ngandu et al., 2010).

\subsection{Communication Cluster}

Figure 1 shows the movement of the influence generated by an injection in the communication sector. The destination sector selected on the basis of yielding the highest average path multipliers from the injection is the building and other construction sector. The communication cluster comprises six sectors ( 2 secondary and 4 tertiary 
sectors), namely communication, trade, building and other construction, real estate, transport and electricity sectors, as illustrated in Figure 1. An examination of the weight on the edges (i.e. induced inter-sectoral transactions) in the cluster reveals a particularly strong connection between four sectors, i.e. communication, trade, real estate, and building and other construction.

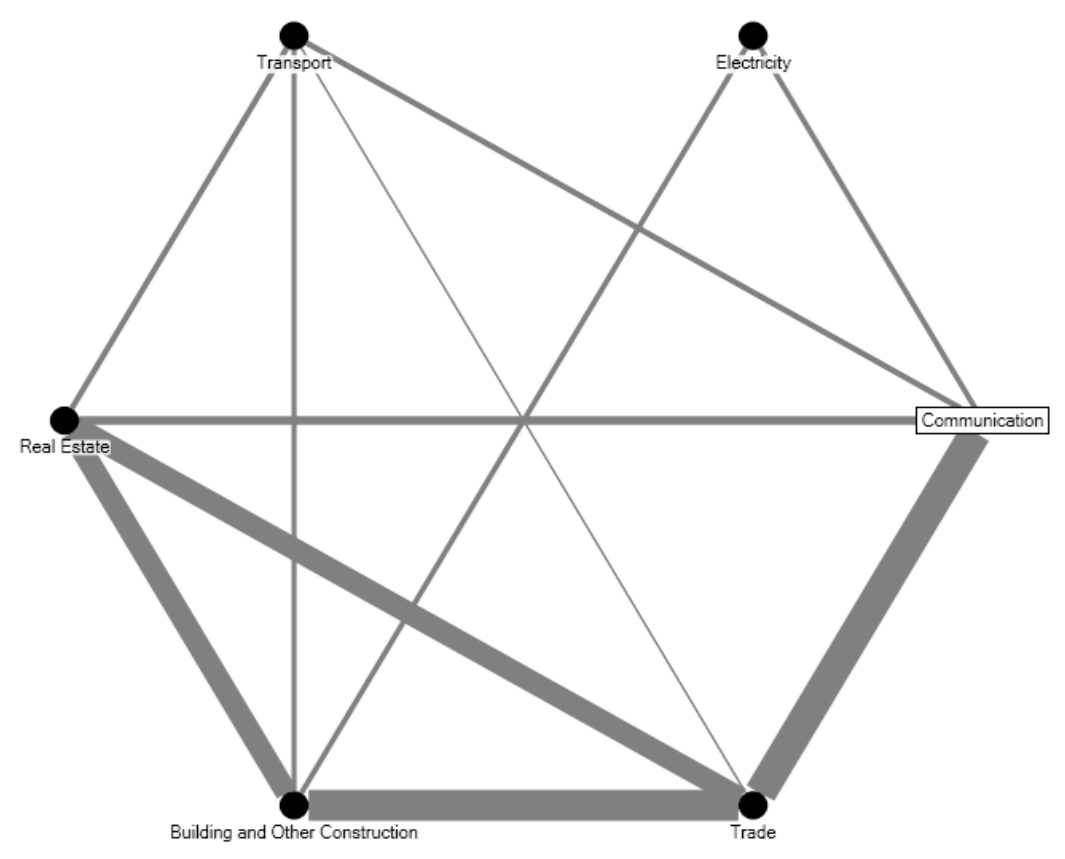

Figure 1. Communication Cluster - Structural Paths To All Commodity Sectors In The NWP

From these results, it is evident that the most important sector in transmitting influence between the communication and building and other construction sectors is real estate. Figure 1 shows that the efficacy of an injection into the communication sector is relatively weak when we consider the number of sectors that benefit. That is, only five sectors will benefit from induced demand increases in the communication sector. In addition, an injection into the communication cluster would generate the most economy-wide effects in terms of PoP, as illustrated in Table 3.

\subsection{Real Estate Cluster}

Figure 2 shows the SPA results for the real estate cluster. A significant proportion of the global influence of the real estate sector on the communication sector is transmitted through a direct path. This indicates that the direct paths are significant in transmitting the global influence. Path analysis reveals that six sectors benefit from the expansion of the real estate sector. Those benefitting the most are the communication and trade sectors. The real estate cluster comprises seven sectors. The three sectors with the weakest effect in the cluster are business services, insurance and community, social and personal services. 


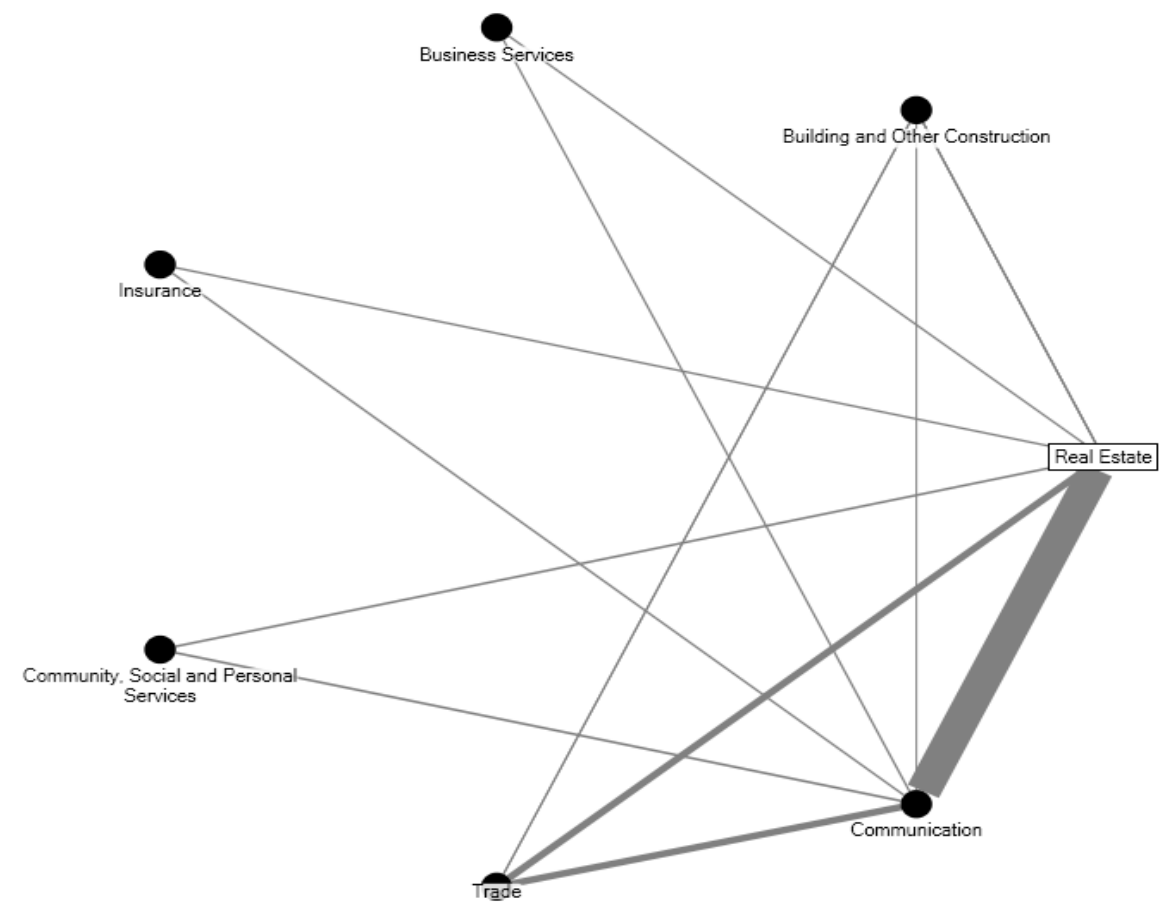

Figure 2. Real Estate Cluster - Structural Paths To All Commodity Sectors In The NWP

\subsection{Grain Mill, Bakery And Animal Feed Products Cluster}

An injection into the grain mill, bakery and animal feed products sector, hereafter referred to as the grain mill cluster, directly transmits the largest increase in production in the communication sector. This elementary path accounts for the largest percentage of the global influence. The grain mill cluster comprises ten sectors spanning the primary, secondary and tertiary sectors. This illustrates that many production activities benefit from an injection in the grain mill cluster; hence, the numerous elementary paths.

The strongest inter-industry linkages in the cluster are observed between (i) grain mill and communication, (ii) grain mill and agriculture, (iii) trade and agriculture, and (iv) grain mill and trade (see Figure 3). The most important sectors in transmitting influence in the grain mill cluster are communication, agriculture and trade. The weakest poles in the cluster (with the least number of inter-industry linkages) are chemicals and chemical products, and business services. A significant proportion of the global influence of grain mill on communication is transmitted through indirect paths. 


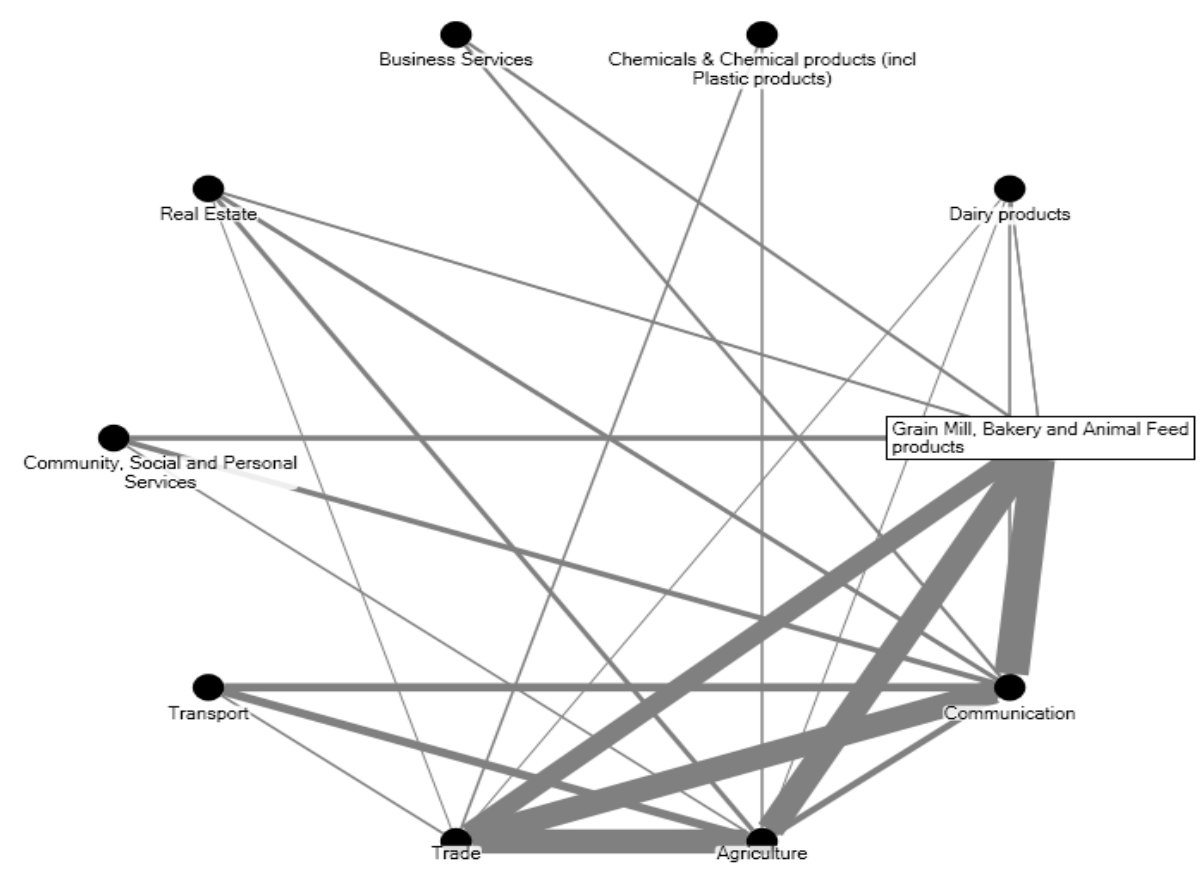

Figure 3. Grain Mill, Bakery And Animal Feed Products Cluster - Structural Paths To All Commodity Sectors In The NWP

\subsection{Building And Other Construction Cluster}

The building cluster comprises eight sectors, as illustrated in Figure 4. Some are secondary and some are tertiary sectors. The strongest inter-industry linkages exist between the building and other construction, trade and communication sectors. Inter-industry linkages in the top three elementary paths between building and other construction and communication were less significant in comparison with indirect effects. The communication sector is the most significant transmitter of influence in the cluster, as evidenced in the most number of linkages with the other sectors in the cluster (see Figure 4). The sectors transmitting the least influence in the cluster are the community, social and personal services, structural metal products and real estate sectors. 


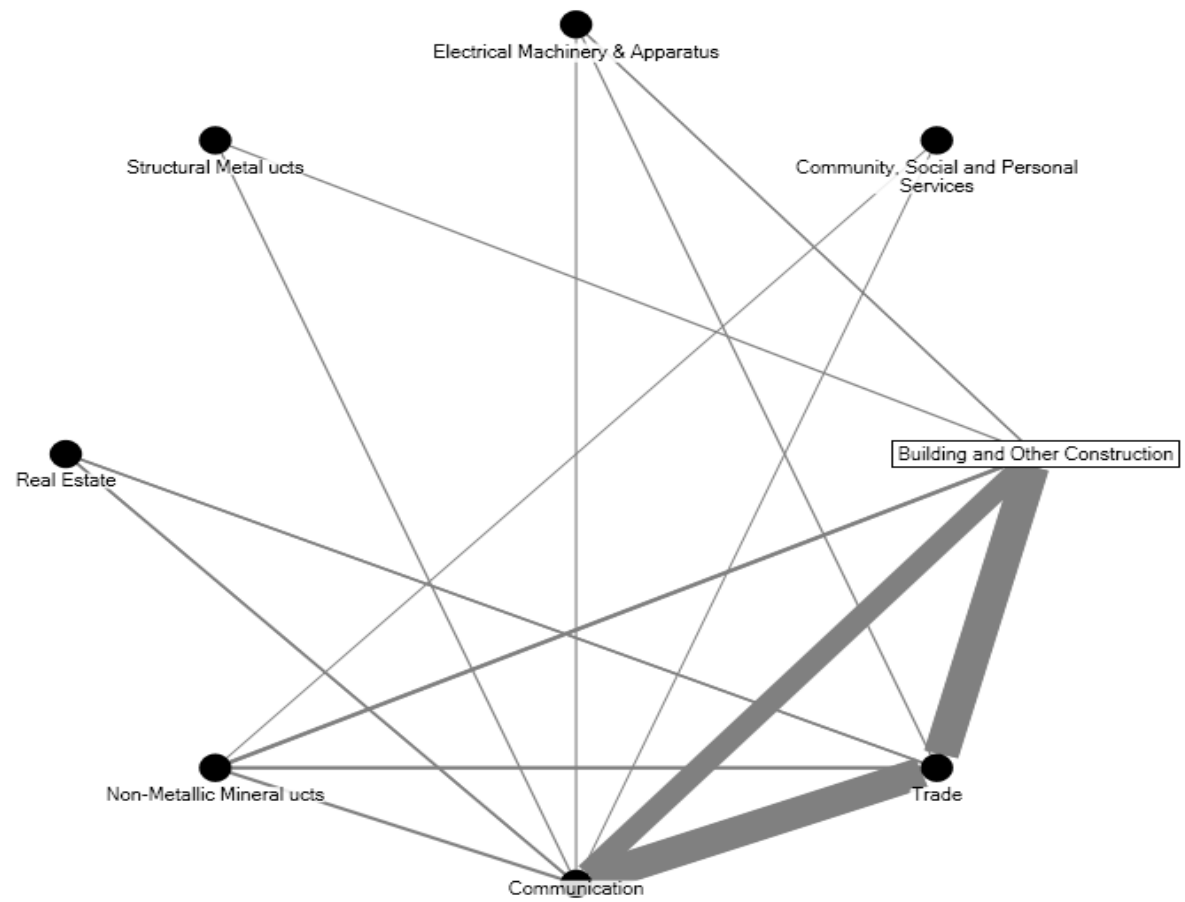

Figure 4. Building And Other Construction Products Cluster - Structural Paths To All Commodity Sectors In The NWP

\subsection{Basic Metal Products Cluster}

Figure 5 shows the structural paths between the basic metal products cluster and all commodities. The trade sector is the most significant transmitter of influence in the basic metals products cluster, which is made up of nine sectors spanning primary to tertiary activities. It is evident that many production activities benefit in the paths of an injection in this cluster. Other important elementary paths in the cluster include real estate, transport and other mining. A significant proportion of the global influence is transmitted through direct paths, indicating the significance of indirect paths in this cluster. 


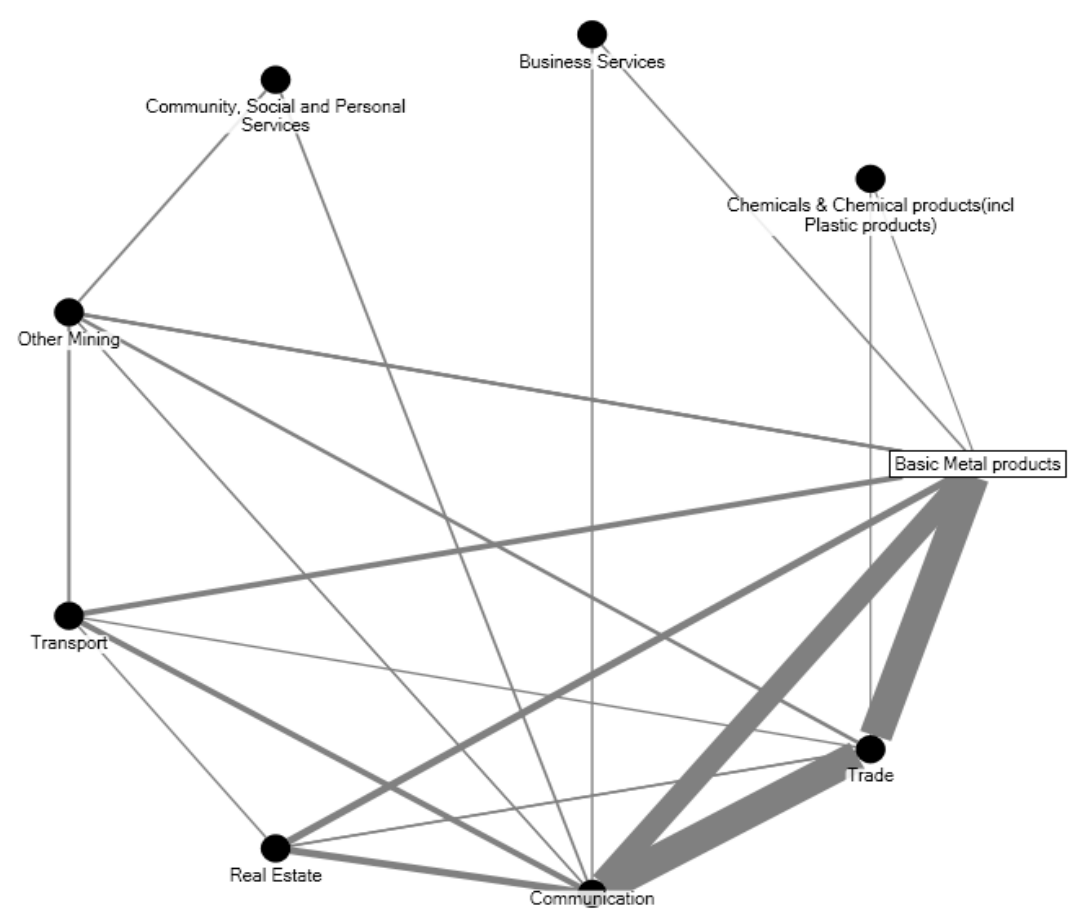

Figure 5. Basic Metal Products Cluster - Structural Paths To All Commodity Sectors In The NWP

\subsection{Other Food Products Cluster}

Figure 6 illustrates the additional production induced on the demand for communication sector inputs by stimuli in the other food products sector. The direct paths of transmitting the global influence are not significant. Figure 6 clearly illustrates that the sectors benefiting the most from an expansion of the other food products sector are agriculture, trade, communication and dairy products. Inter-industry transactions between these sectors and the other food products sector are significant, as shown by the edge weights in Figure 6. From Figure 6 it is evident that an injection in the other food products cluster is effective in generating high inter-industry linkages (number of thick lines) and additional production in the other sectors in the cluster. Several production activities benefit both directly and indirectly from an injection in the other food products sector. This is because the other food products utilise inputs from the agriculture and dairy products sectors and sell its output to other sectors and institutions in the economy through the trade sector. The communication sector is utilised to advertise the products of the other food products sector. 


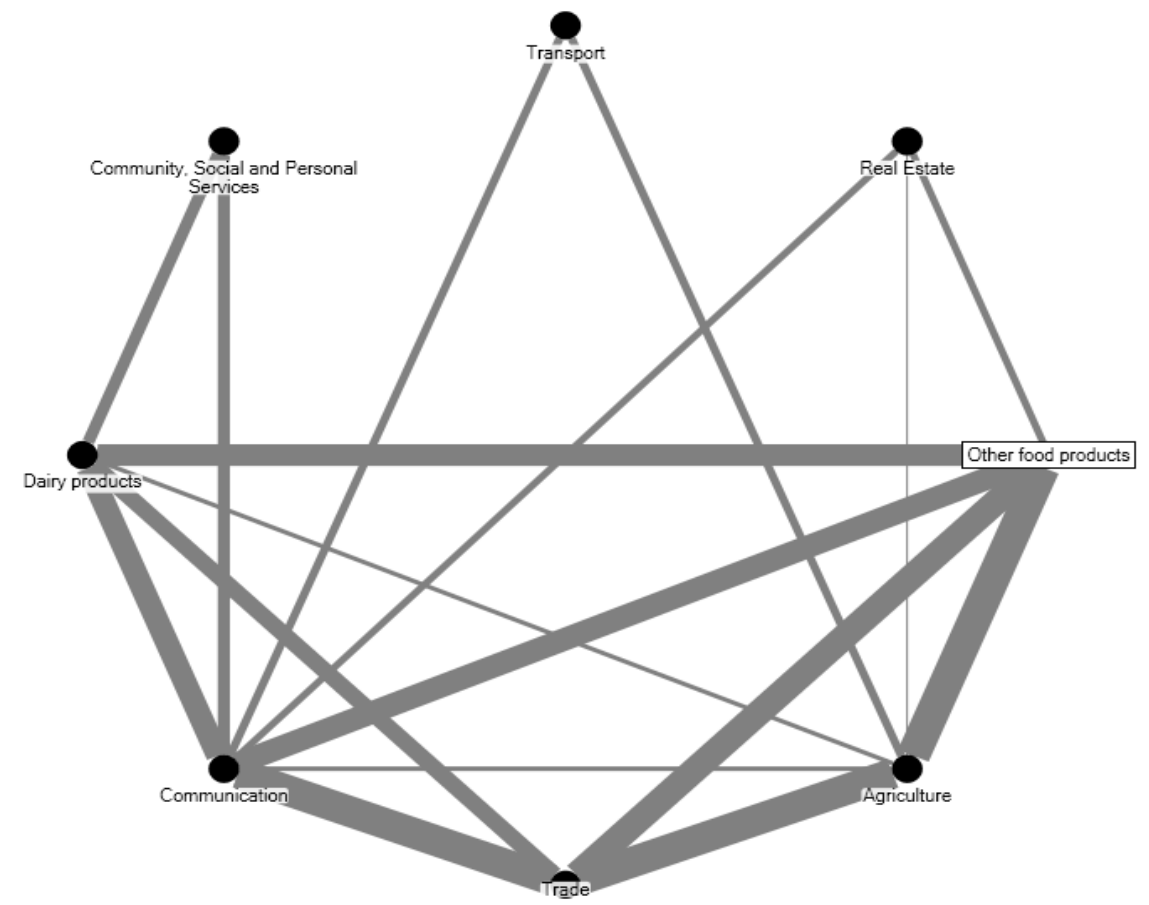

Figure 6. Other Food Products Cluster - Structural Paths To All Commodity Sectors In The NWP

\subsection{Agriculture Cluster}

The core structure of the agriculture cluster consists of ten industries, as shown in Figure 7. The most significant elementary path for the transmission of the global influence in the agriculture cluster is an indirect path through trade and communication. Other significant indirect elementary paths in the agriculture cluster are through the transport and communication sectors and the real estate and communication sectors, respectively. The agriculture cluster comprises a number of elementary paths between the ten sectors. Figure 7 illustrates that this cluster comprises several inter-industry linkages. For example, the cluster is strongly connected to the trade sector which, in turn, is the most important sector to transmit influence in the cluster. The domination of the trade sector in this cluster suggests that developments in the cluster are transmitted through activities within the trade sector. 


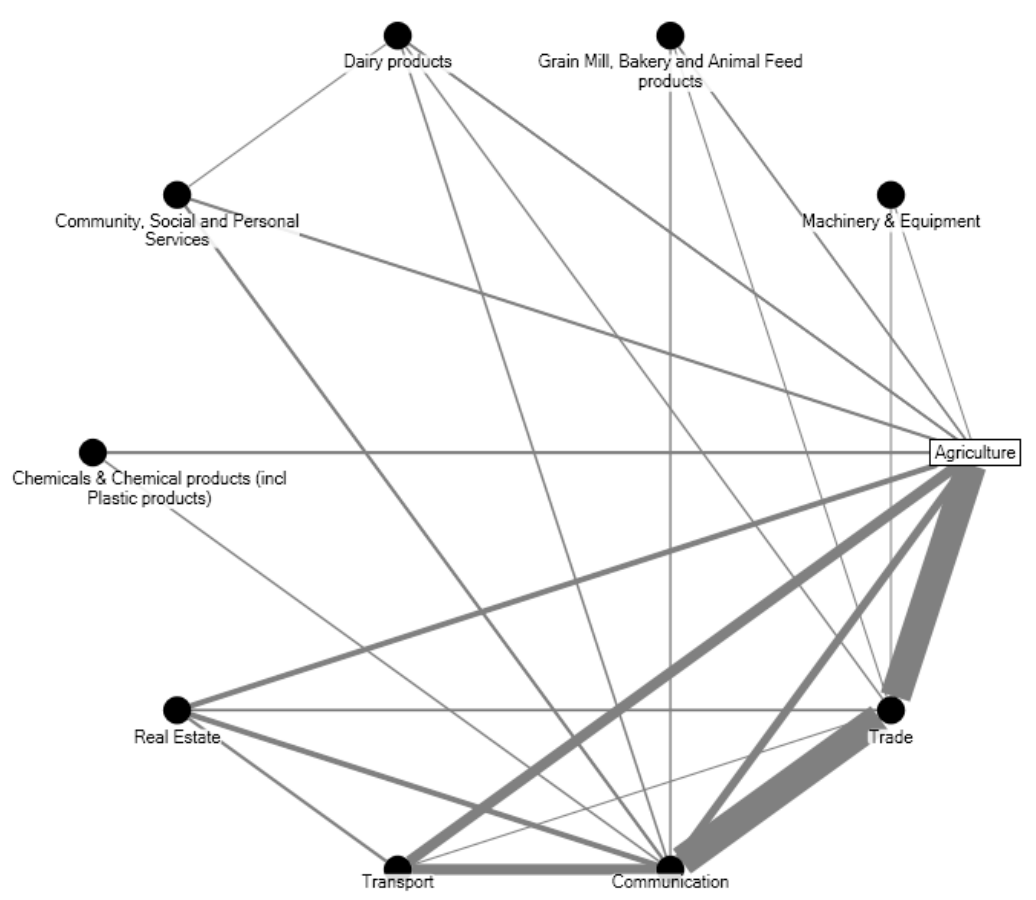

Figure 7. Agriculture Cluster - Structural Paths To All Commodity Sectors In The NWP

\subsection{Non-Metallic Mineral Products Cluster}

The non-metallic mineral products cluster comprises eight sectors, namely non-metallic mineral products; other mining; real estate; business services; transport; community, social and personal services; communication; and trade. The destination sector, selected on the basis of yielding the highest average path multipliers from the injection, is the communication sector. The highest proportion of this global influence is exercised indirectly through the trade and communication sectors, with the trade sector being the most important sector in transmitting influence in the cluster. In this regard the trade sector appears the most times in the elementary paths between the non-metallic minerals products and communication sectors. Figure 8 shows that the efficacy of an injection into the non-metallic mineral products cluster is relatively weak when one considers the number of sectors that benefit. There are only seven sectors that will benefit from induced demand increases in the non-metallic mineral products cluster. 


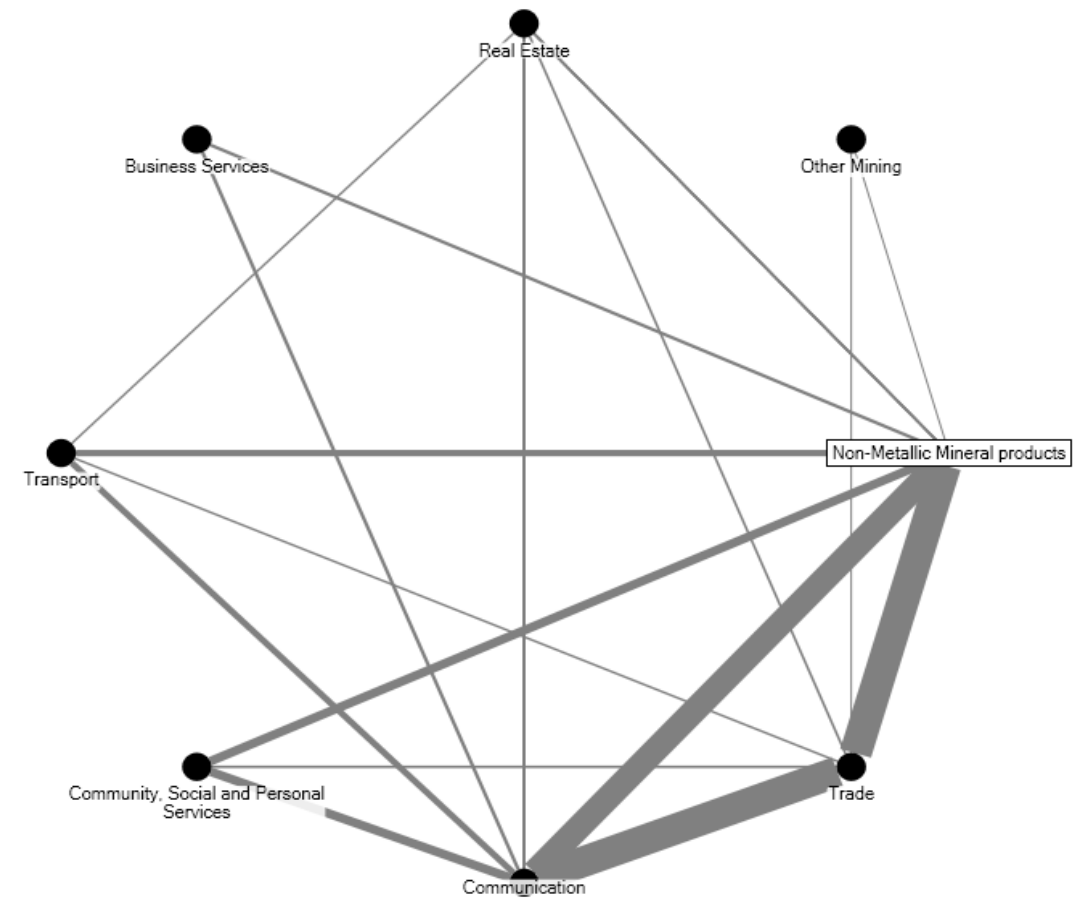

Figure 8. Non-Metallic Mineral Products Cluster - Structural Paths To All Commodity Sectors In The NWP

\subsection{Trade Cluster}

Figure 9 shows the SPA results for the trade cluster. The destination sector selected on the basis of yielding the highest average path multipliers from the injection in this sector is the basic metal products sector. The most significant elementary path between trade and basic metal products is an indirect path. A significant proportion of the global influence of an injection in the trade sector is transmitted to the basic metals sector through the communication sector. The indirect paths are more significant in transmitting influence than direct paths in the trade cluster. The trade cluster comprises fourteen sectors (see Figure 9). This shows that the efficacy of an injection into the trade sector is strong when one considers the number of sectors (i.e. fourteen) that benefit from induced demand increases in the trade sector. 


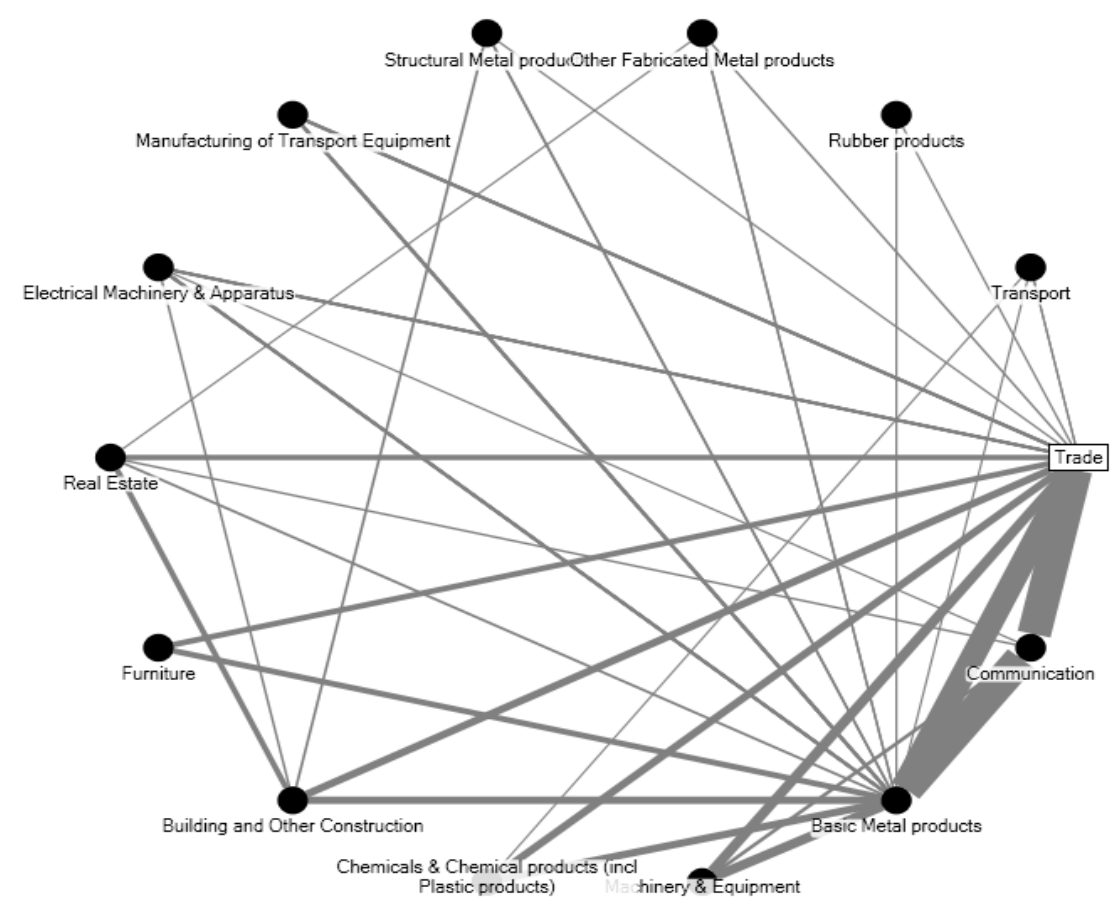

Figure 9. Trade Cluster - Structural Paths To All Commodity Sectors In The NWP

\subsection{Dairy Products Cluster}

The dairy products cluster was identified as the $10^{\text {th }}$ industrial cluster yielding the most economy-wide effects for the NWP. The core structure of the dairy products cluster comprises 9 industries, as shown in Figure 10. The most significant elementary path for the transmission of the global influence in the dairy products cluster is a direct path through the communication sector. Both the direct and indirect paths are significant for transmitting influence in the cluster. The dairy products cluster comprises several indirect elementary paths between the nine sectors (see Figure 10), suggesting that firms in the relevant industries have multiple inter-industry transactions across the region. The formation of an industrial cluster can create close associations between the firms in these industries, thereby improving their competitiveness. The most important sector for transmitting influence between the dairy products and communication sectors is agriculture. Agriculture is the most important because it appears the most number of times in the elementary paths between the dairy products and communication sectors. 


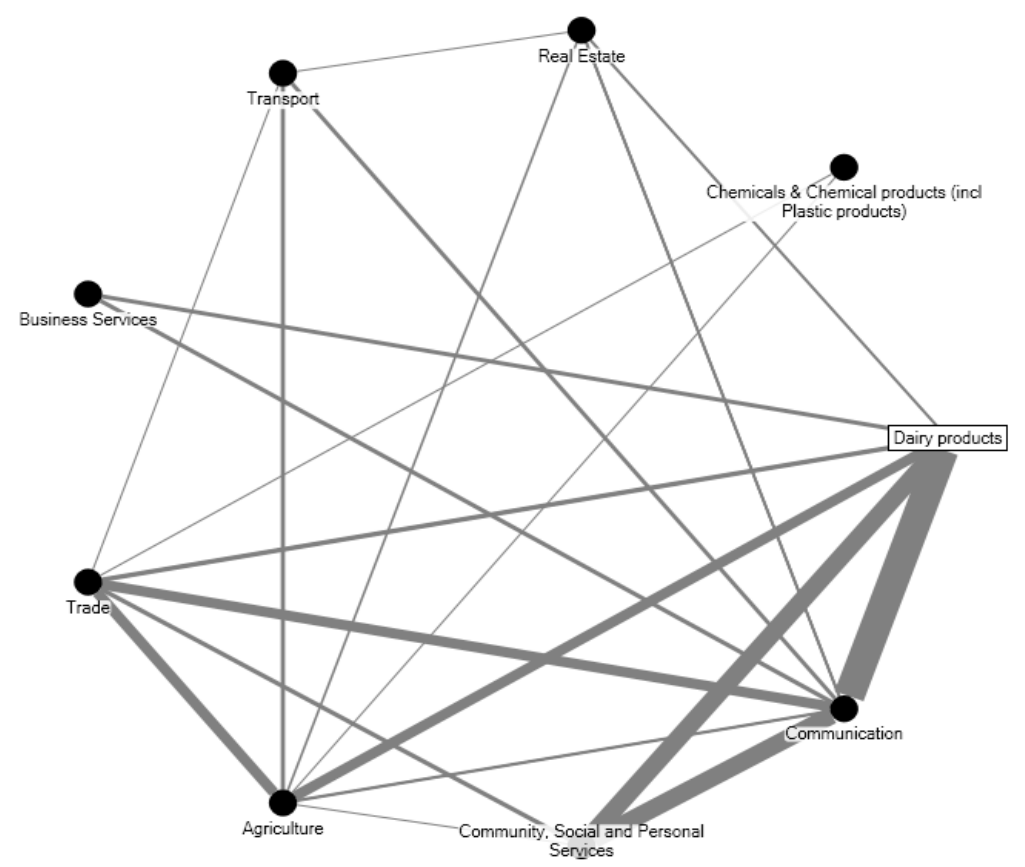

Figure 10. Dairy Products Cluster - Structural Paths To All Commodity Sectors In The NWP

\section{CONCLUSION}

Resource-dependent regions have been found to be vulnerable to external shocks and to have lagged in development. This means that such regions' long-term prospects of generating sustainable economic growth and achieving competitiveness are limited. The literature suggests that industrial cluster formation can enhance the competitiveness and productivity of the various sectors that constitute the cluster, and yield economy-wide growth. It can also alter the economic structure of the region from a specialised, resource-dependent one to one that accommodates more diversified economic activities. Furthermore, industrial cluster formation results in sub-regional economies differentiating themselves and fanning out into influential networks which, in turn, give rise to additional nerve centres.

South Africa's NWP is highly specialised and dependent on a few sectors. For example, more than $60 \%$ of the provincial output is concentrated in four sectors. This paper set out to identify industrial clusters in South Africa's NWP as the basis of a strategy to advance economic diversification and enhance competitiveness in the provincial economy. Ten industrial clusters that had strong, existing inter-industry linkages were identified by applying the SPA and PoP methods to a 2006 provincial SAM for the NWP. The results of the study point to ten clusters that should be targeted as focal points for economic diversification in the NWP, namely (i) communication, (ii) real estate, (iii) grain mill, bakery and animal feed products, (iv) building and other construction, (v) basic metal products, (vi) other food products, (vii) agriculture, (viii) non-metallic mineral products, (ix) trade, and (x) dairy products.

Through the process of identifying industrial clusters, it was revealed that there are strong, existing interindustry linkages among the sectors, and that these can be enhanced through industrial cluster formation. Moreover, the PoP results indicate that the identified industrial clusters are powerful and can be used as engines of growth and diversification in the NWP. Increasingly, those researching the phenomenon of industrial cluster formation as well as government practitioners are realising that industrial clusters are an important source of sustainable growth and competitiveness. Indeed, the results from this particular study suggest that the shortcomings linked to specialisation in resource-dependent regions can be addressed through industrial cluster formation. Specifically, industrial clusters can enhance economic diversification in the NWP as each industrial cluster comprises an extensive array of sectors. 
Furthermore, industrial cluster formation has the potential to avail the various benefits derived from this form of economic cooperation to firms in the NWP.

This study has demonstrated the use of a particular methodological framework used to identify and prioritise industrial clusters. Often, from a central planning point of view, it is difficult to select sectors and regions on which to focus economic development efforts as development strategies are often designed to be holistic. It is recommended that the government (national and provincial) play a catalytic and supportive role when it comes to industrial cluster development in resource-dependent regions. A catalytic role involves bringing vested interests together to initiate collaboration in order to smooth the way for industrial cluster formation. This is an important step in determining the existing levels of cooperation between firms in the industrial clusters and generating interest in the potential benefits of cluster formation. It is important because the quantitative analysis conducted in this study does not offer qualitative insights into industrial cluster characteristics, such as the prevalence of active networks, learning and innovation, and sharing of information or equipment. Bringing the vested interests together will help to determine whether any forms of cooperation can be forged.

It is further recommended that the government assess its capabilities in terms of facilitating industrial cluster formation with a view to exposing any shortcomings. Once this is done, the government should put its efforts into creating a business environment that is conducive to cluster formation in resource-dependent regions. Chiaroni and Chiesa (2006) assert that a favourable environment is the key driver to industrial cluster formation. Such an environment would be characterised by a scientific base, adequate finance and a compelling industrial context. The provision of these elements by the government helps to reduce the start-up costs associated with a cluster, thereby improving the cluster's chances of success. In addition, a favourable environment not only benefits the firms that make up the cluster, but other firms outside the cluster as well. If a favourable environment exists, firms will establish branches in the region in order to take advantage of the benefits flowing from the formation of industrial clusters.

By putting industrial cluster formation under the spotlight through a multi-dimensional analysis, this paper offers new and valuable insights into the cluster phenomenon and the strategic role it plays, and will continue to play, in driving economic diversification and growth. Not only will the literature be richer for this study's findings but the government of the North West Province, in particular, will be able to address the province's diversification and productivity challenges from a more informed base.

\section{AUTHOR INFORMATION}

Noleen Pisa is a lecturer at the Department of Transport and Supply Chain Management at the University of Johannesburg. She holds a PhD in International Trade as well as a M.Com in International Trade (with distinction) from the North West University (Potchefstroom Campus). Her research interests include competitiveness, industrial cluster formation, economic and socio-economic impact assessments, market analysis, market accessibility, policy analysis and economic modelling and export promotion. She has worked as a consultant for the International Trade Centre in Geneva, Switzerland. E-mail: 21246165@nwu.ac.za (corresponding author)

Riaan Rossouw is a quantitative economist with more than 11 years' consulting, research and teaching experience. He is currently an independent consultant and extraordinary associate professor of economics in the TRADE (Trade and Development) research niche area at the North-West University's Potchefstroom Campus. Riaan is a microeconomist with more than 11 years' applied research and teaching experience. He is currently an associate professor in the School of Economics at the North-West University. His research interests include social and economic dimensions of inequality, economic impact assessment, decision support systems as well as applied/computable general equilibrium modelling, particularly as applied in the African (and South African) contexts, with a special focus on regional disparities, labour markets, fiscal reform, tourism, energy policy, development planning and international trade. Riaan has carried out consultancy work for numerous entities, including governmental departments, financial institutions, private companies, international organisations, international business schools, and real economy institutions such as mining houses, freight transport companies and utility providers. E-mail: riaan.rossouw@nwu.ac.za 
Wilma Viviers, since July 2014, is the holder of the prestigious WTO Chair, leader of the TRADE research entity and NRF-rated researcher at the North-West University (Potchefstroom Campus). Prof Viviers' research interest in the realisation of and strategies to improve South Africa's trade performance and competitiveness are acknowledged both locally and internationally. Notably, the Decision Support Model (DSM) for the identification of South African export opportunities - which she has launched in this country - is being lauded in both government and business circles as a refreshingly efficient approach to export market selection. Prof Viviers sits on several national and international committees and has received numerous awards in recognition of her ground-breaking research over the years. E-mail: wilma.viviers@nwu.ac.za

\section{REFERENCES}

Alers. L. (2014). Counting costs of mining strikes worst yet to come. Biznews.com. Retrieved from: http://www.biznews.com/thought-leaders/2014/07/counting-costs-sa-mining-strikes-worst-yet-comeanalyst. Date of access: 13 January 2015.

Birch, K., Mackinnon, D. \& Cumbers, A. (2010) Old industrial regions in Europe: A comparative assessment of economic performance. Regional Studies, 44(1), 35-53.

Bishop, P \&Gripaios, P. (2007). Explaining spatial patterns of industrial diversity: An analysis of subregions in Great Britain. Urban Studies, 44 (9): 1739-1757.

Böwer, U., Geis, A. \& Winkler, A. (2007). Commodity price fluctuations and their impact on monetary and fiscal policies in Western and Central Africa (April 2007). ECB Occasional Paper No. 60.

Bryan, J., Jones, C. \& Munday, M. (2005). The potential of key sectors and clusters in Wales; a multi-criteria approach. Working Paper No. 2005.1, WERU, Cardiff University.

Chapman, K., Mackinnon, D. \& Cumbers, A. (2004). Adjustment or renewal in regional clusters? A study of diversification amongst SMEs in the Aberdeen oil complex. Transactions of the Institute of British Geographers, 29, 382-396.

Chiaroni, D. \& Chiesa, V. (2006). Forms of creation of industrial clusters in biotechnology. Technovation, 26(9), 1064-1076.

Debowicz, D., Dorosh, P., Haider, H.S. \& Robinson, S. (2013). A disaggregated and macro-consistent social accounting matrix for Pakistan. Journal of Economic Structures, 2(4), 1-30.

Defourny, J. \& Thorbecke, E. (1984). Structural path analysis and multiplier decomposition within a social accounting matrix framework. The Economic Journal, 94, 111-136.

Dietzenbacher, E. (1992). The measurement of inter-industry linkages: key sectors in the Netherlands. Economic Modelling, 9: 419-437.

Doeringer, P. B. \& Terkla, D. G. (1995). Business strategy and cross-industry clusters. Economic Development Quarterly, 9(3): 225-238.

DTI/ Deloitte. (2014). South Africa: Investor's Handbook 2013/14 . Retrieved from: http://www2.deloitte.com/content/dam/Deloitte/za/Documents/tax/ZA_Investor\%E2\%80\%99sHandbook20 13-2014_10042014.pdf. Date of access 14 January 2015.

Eitzen, H.C. (2012). Dilemmas of diversification: Regional economic development and business-industrial clusters in China and Kazakhstan. Journal of Emerging Knowledge on Emerging Markets, 4(1/2): 2-26.

Enright, M. J. (2003). Regional clusters: what we know and what we should know. In BröCker, J., Dohse, D. \& Soltwedel, R. (Eds) Innovation Clusters and Interregional Competition. p409. Springer: Berlin; London.

Hall, P. \& Whiteford, A. (1998). The economy of Gauteng, in KOK, P. South Africa's magnifying glass: a profile of Gauteng province. Human Sciences Research Council, pp. 185-220.

Harun, M., Zakariah, A.R. \& Azali, M. (2012). Constructing a social accounting matrix framework to analyse the impact of public expenditure on income distribution in Malaysia. Jurnal Ekonomi Malaysia, 46(2), 63-83.

Hirschman, A.O. (1958). The strategy of economic development. Yale University Press, New Haven, CT. Retrieved from: http://www.compete.org/images/uploads/File/PDF\%20Files/CoC_Pitts_cluster_final.pdf. Date of access: 28 October 2014.

Imbs, J. \& Wacziarg, R. (2003). Stages of diversification. American Economic Review, 93(1): 63 - 86.

Kagawa, S., Kondo, Y., Nansai, K. \& Suh, S. (2010). Detecting energy clusters from the automobile supply chain: spectral clustering approach. Paper presented at the 18th International Input-Output Conference, 20-25 June, 2010, The University of Sydney. 
Kingstone, P. (2012). Brazil's reliance on commodity exports threatens its medium- and long-term growth prospects. Retrieved from: http://www.americasquarterly.org/kingstone. Date of access: 15 May 2014.

Lee, T-L. (2006). Action strategies for strengthening industrial clusters in Southern Taiwan. Technology in Society, 28: 533-552.

Lima, M., Cardenete, A. \& Vallés Ferrer, J. (2003). Structural path analysis: Applications to structural changes in the Andalusian economy 1990-1999, European Regional Science Association ERSA 2003 Congress.

Luo, J. (2013). Which industries to bail out first in economic recession? Ranking US industrial sectors by the powerof-pull. Economic Systems Research, 25(2), 1-23.

Madsen, E.S., Smith, V. \& Dilling-Hansen, M. (2004). Industrial clusters, firm location and productivity: some empirical evidence for Danish firms. Working Papers 03-26, University of Aarhus, Aarhus School of Business, Department of Economics.

Malacarne, M. (2013). The role of cluster organisations in supporting emerging industries via cross-sectorial innovation. Paper presented at ECIA PLP meeting - Milano, 8 November 2013.

Marshall, A. 1890 (1920). Principles of economics. $8^{\text {th }}$ ed. London: Macmillan.

Martin, R. \& Sunley, P. (2003). Deconstructing clusters: chaotic concept or policy panacea? Journal of Economic Geography, 3, 5-35.

Morosini, P. (2004). Industrial clusters, knowledge integration and performance. World Development, 32(2), 305326.

National Governors Association (NGA) (2002). A governor's guide to cluster based economic development. Washington D.C. Retrieved from: http://www.nga.org. Date of access: 25 October 2014.

Newman, M.E.J. (2008). Mathematics of networks, in Blume, L.E. \& Durlauf, S.N. (Eds) The New Palgrave Encyclopaedia of Economics, 2nd edition. Palgrave Macmillan, Basingstoke.

Ngandu, S., Garcia, A.H. \& Arndt, C. (2010). The economic influence of infrastructural expenditure in South Africa: a multiplier and structural path analysis, Development Policy Research Unit, Employment Promotion Programme and Trade and Industrial Policy Strategies Conference, 27-29 October 2010. Johannesburg, South Africa.

Organisation for Economic Cooperation and Development/United Nations (2011). Economic diversification in Africa: a review of selected countries. OECD Publishing. Retrieved from: http://www.oecd.org/investment/investmentfordevelopment/46148761.pdf. Date of access: 30 April 2014.

Parra, J.C. \& Wodon, Q. (2009). SimSIP_SAM: a tool for the analysis of Input - Output tables and Social Accounting Matrices, Mimeo. World Bank, Washington D.C.

Pisa, N. 2014. Identifying industrial clusters for competitiveness: Policy implications for economic development in the North West Province of South Africa. Unpublished PhD Thesis, North West University (Potchefstroom Campus), South Africa.

Platinum Wage Negotiations. (2014). Financial impact of strike. Retrieved from: http://www.platinumwagenegotiations.co.za. Date of access: 14 January 2015.

Porter, M. E. (1998). The competitive advantage of nations (with a new foreword). The Free Press, New York.

Porter, M.E. (2000). Location, completion and economic development. Economic Development Quarterly, 14: 2334.

Quantec Easy Data (2014). Regional indicators. Retrieved from: http://www.easydata.co.za. Date of access: 1 February 2014.

Roberts, D. (2005). The role of households in sustaining rural economies: a structural path analysis. European Review of Agricultural Economics, 32, 393-420.

Robinson, S., Cattaneo, A. \& El-Sai, M. (2001). Updating and estimating a Social Accounting Matrix using cross entropy methods. Economic Systems Research, 13(1): 47-64.

Roelandt, T. \& Hertog, P. (1999). Boosting innovation: the cluster approach, OECD- Proceedings: Paris.

Ross, M., Lujala, P. \& Rustad, S. (2012). Horizontal inequality, decentralizing the distribution of natural resource revenues, and peace, in LUJALA, P. and RUSTAD, S.A. High-Value Natural Resources and Peace Building (Eds). Earthscan, London.

Ruan, J. \& Zhang. X. (2009). Finance and cluster-based industrial development in China. Economic Development and Cultural Change, 58(1): 143-64.

Schmitz, H. (1997). Collective efficiency and increasing returns. Cambridge Journal of Economics, 23(4):465-483.

Schmitz, H. (1999). Global competition and local cooperation: success and failure in the Sinos Valley. Brazil. World Development, 27 (9): 1627-50. 
Schmitz, H. \& Nadvi, K. (1999). Clustering and industrialisation: Introduction. World Development, 27(9): 15031514.

Seeley, J.R. (1949). The net of reciprocal influence: A problem in treating socio-metric data. Canadian Journal of Psychology, 3, 234-240.

Shantong, L., Ying, G. \& Jianwu, H. (2004). SAM-based multiplier analysis for China's economy, Paper prepared for the XIIINFORUM World Conference.

Shields, M., Barkley, D. and Emery, M. (2010). Industry clusters and industry targeting, In Goetz, S.J., Deller, S.C. \& Harris, T.R. eds. Targeting Regional Economic Development, pp. 35-46. Taylor and Francis, New York.

Sindzingre, A.N. (2011). The constraints to structural transformation in commodity exporting countries: China's trade-investment-aid relationships with Sub-Saharan Africa. Retrieved from: http://www.nai.uu.se/ecas4/panels/1-20/panel-1/Alice-Sindzingre-Full-paper.pdf. Date of access: 14 March 2012.

Singh, S. (2014). Effects of the mining strikes on the South African economy. Retrieved from: http://www.miningreview.com/effects-of-the-mining-strikes-on-the-south-african-economy._Date of access: 13 January 2015.

Solomons, I. (2014). Platinum strike consequences starting to take shape. Retrieved from: http://www.miningweekly.com/article/platinum-strike-consequences-starting-to-take-shape-2014-08-22. Date of access: 13 January 2015.Sonobe, T. \& Otsuka, K. (2006). Cluster-based industrial development: an East Asian model. New York: Palgrave Macmillan.

South African Reserve Bank (SARB). (2014). Quarterly bulletin, June 2014. . Retrieved from: https://www.resbank.co.za/Lists/News\%20and\%20Publications/Attachments/6273/01Full\%20Quarterly\%2 0Bulletin\%20\%E2\%80\%93\%20June\%202014.pdf. Date of access: 13 January 2015.

Statistics South Africa. (2013). Statistics by place. http://beta2.statssa.gov.za/?page_id=964. Date of access: 16 Aug. 2013.

Torre, A. (2008). On the role played by temporary geographical proximity in knowledge transmission. Regional Studies, 6:869-89.

United Nations Conference on Trade and Development (UNCTAD) (2012). Excessive commodity price volatility: Macroeconomic effects on growth and policy options. Contribution from the UNCTAD Secretariat to the G20 Commodity Markets Working Group. Retrieved from: http://unctad.org/en/Docs/gds_mdpb_G20_001_en.pdf

Wasserman, S. \& Faust, K. (1994). Social network analysis: methods and applications. Cambridge University Press, Cambridge, New York. 


\section{NOTES}

